\title{
The Effect of Dry Yeast Fermentation on Chemical Composition and Protein Characteristics of Blue Lupin Seeds
}

\author{
Małgorzata Kasprowicz-Potocka ${ }^{1 *}$, Paulina Borowczyk ${ }^{1}$, Anita Zaworska ${ }^{1}$, \\ Włodzimierz Nowak ${ }^{1}$, Andrzej Frankiewicz ${ }^{1}$ and Piotr Gulewicz ${ }^{2}$ \\ ${ }^{1}$ Poznan University of Life Sciences, Department of Animal Nutrition and Feed Management, \\ Wołyńska 33, PL-60-637 Poznan, Poland \\ ${ }^{2}$ Poznan Science and Technology Park of Adam Mickiewicz University Foundation, Rubież 46, \\ PL-61-612 Poznan, Poland
}

Received: October 20, 2015

Accepted: February 29, 2016

\begin{abstract}
Summary
The effect of 24-hour fermentation of lupin seeds by different yeast strains on their chemical composition was determined. After fermentation, the mass fraction of proteins increased and their in vitro digestibility and biological activity significantly improved. The amino acid profile of fermented products was similar to that of raw lupin seeds. The significant reduction in the mass fraction of oligosaccharides and phytate, but not of alkaloids was found. The $\mathrm{pH}$ level of fermented products decreased as a consequence of the increase of lactic and propionic acid mass fractions. The most favourable changes in the chemical composition of blue lupin seeds were obtained in fermentation with Saccharomyces cerevisiae baker's yeast and Fermivin 7013 strain.
\end{abstract}

Key words: yeast, fermentation, lupin, nutritional value, antinutritional factors

\section{Introduction}

The last decade has seen an increased interest in the cultivation of blue lupin after the discovery of its anthracnose resistance and high protein content, but the presence of antinutritional factors (ANF) adversely affects the palatability of seed (alkaloids) and utilization of nutrients ( $\alpha$-galactosides and phytates) by monogastric animals (1). Blue lupin seeds also have a lower energy level (e.g. metabolizable energy in diets for pigs) than the other lupin species, because of the higher content of crude fibre, fibre fractions (acid detergent fibre (ADF) and neutral detergent fibre (NDF)) and non-starch polysaccharides in seeds, which are partially non-digestible (2). For this reason, attempts are being made to improve the nutritional value of blue lupin seeds, especially by reducing the ANF content and increasing protein and carbohydrate utilization. There are many methods for removing undesirable substances from the seeds of leguminous plants (3). Ex- tractions with different solvents yield the seeds with a high protein content, without non-nutritive substances (4). Sprouting is a very simple method, but it causes many changes in the chemical composition and microbiological quality, which can be potentially undesirable in some conditions (5-7). Fermentation is an easy and cheap method of improving nutritional value of feed and food. Fermentation of lupin was successfully carried out with the use of fungi (Aspergillus oryzae and Rhyzopus oryzae), bacteria (Bacillus subtilis and Lactobacillus brevis) or by natural fermentation. It also contributed to the improvement of sensory qualities, increasing the availability of minerals and reducing the concentrations of phytates (2-4). There are no studies available concerning lupin seeds fermented by yeast. Yeast fermentation is generally used in practice to increase protein levels in feed with low protein content and rich in starch. Therefore, more studies focus only on starch-containing components (pea, faba bean, etc.). Lupin seeds store energy in the form of non-starch polysac- 
charides, mostly oligosaccharides of the raffinose family, glucose, galactose, arabinose and xylose. Yeast fermentation of starch substrates in aerobic conditions leads to the production of mainly carbon dioxide and water, and stimulates appropriate propagation of yeast, generating large amounts of biomass formation (8). However, depending on the species and strain, yeast can utilize various sources of nutrients, such as oligosaccharides, simple sugars, amino acids or industrial waste (8-10). Research provided by Trojanowska et al. (11) shows that the lupin extract, containing mainly oligosaccharides and alkaloids, can be a cultural medium for the development of certain strains of yeast, especially Torula sp. and Saccharomyces sp. During yeast fermentation, the product is enriched with high-value protein of microbial origin and it can also improve the digestibility of protein and amino acid profile and reduce the concentration of antinutritional factors (12-16). Fermented products, in addition to the nutrient content (protein and vitamins), usually include live, dried or lyophilized cells of lactic acid bacteria or yeast, which can work probiotically or prebiotically on digestive tract microflora $(8,10,17-19)$.

The innovation of the presented work is an attempt of nutritive improvement of blue lupin seeds by fermentation with different species of yeast. The hypothesis has been put forward that products obtained by yeast fermentation of lupin seeds will be characterized by a higher nutritional value than unprocessed seeds, and could be a potential new alternative protein source in human and animal nutrition with reduced antinutritional compounds and a higher energy value. Therefore, the aim of the study is to determine the effect of aerobic fermentation of lupin seeds using different strains of active dry yeast on the chemical composition of the obtained lupin products.

\section{Materials and Methods}

\section{Lupin seeds and yeast strains}

Lupinus angustifolius cv. Neptun (registered in 2009) was chosen for the study. Seeds were obtained from the Plant Breeding Smolice Ltd., IHAR Przebedowo Branch, Przebedowo, Poland. Active dry yeasts Saccharomyces cerevisiae: baker's yeast (Dr. Oetker, Bielefeld, Germany), Bayanus G-995 (Starowar, Sulejówek, Poland), Fermivin ${ }^{\circledR} 7013$ strain (Biovin, Łódź, Poland) and Saccharomyces carlsbergensis Fermentis (Lesaffre, Wołczyn, Poland) were used for fermentation. The number of active yeast cells and saccharolytic activity were: of baker's yeast $1.8 \cdot 10^{10}$ cells/g and $125 \mathrm{~mL}$ of $\mathrm{CO}_{2}$ per $1 \mathrm{~g}$ of yeast per $\mathrm{h}$, of Bayanus $2.8 \cdot 10^{9}$ cells $/ g$ and $28 \mathrm{~mL}$ of $\mathrm{CO}_{2}$ per $1 \mathrm{~g}$ of yeast per $\mathrm{h}$, of Fermivin $^{\circledR}$ strain $70131.4 \cdot 10^{10}$ cells/g and $11 \mathrm{~mL}$ of $\mathrm{CO}_{2}$ per $1 \mathrm{~g}$ of yeast per $\mathrm{h}$, and of Saccharomyces carlsbergensis $1.6 \cdot 10^{10}$ cells/g and $11 \mathrm{~mL}$ of $\mathrm{CO}_{2}$ per $1 \mathrm{~g}$ of yeast per $\mathrm{h}$, respectively.

\section{Fermentation}

Seeds were soaked in $2.5 \mathrm{~g} / \mathrm{L}$ of sodium hypochlorite for $10 \mathrm{~min}$ to reduce natural microbial activity before fermentation by yeast and then washed with distilled water to obtain neutral $\mathrm{pH}$, dried and ground in a laboratory mill. Samples of seeds (100 g) were weighed into glass ves- sels and mixed with $400 \mathrm{~mL}$ of water. Dishes were placed on magnetic stirrers and after the initial mixing for 30 min, $1 \%$ of each of the dry yeasts listed above was added. Fermentations were carried out under aerobic conditions (natural $\mathrm{pH}=5.5$ ) for $24 \mathrm{~h}$ in a continuous mixing system. After that, the yeast enzymes were deactivated for $10 \mathrm{~min}$ at $70{ }^{\circ} \mathrm{C}$, and the material was dried at $55^{\circ} \mathrm{C}$. Each product was obtained in four replications.

\section{Chemical analyses}

For chemical analysis, the samples were ground to pass through a $0.5-\mathrm{mm}$ sieve. Dry matter (DM), crude protein $(\mathrm{CP})$, ether extract (EE), crude fibre $(\mathrm{CF})$, crude ash (CA), acid detergent fibre (ADF) and neutral detergent fibre (NDF) of raw seeds and fermented products were analyzed in duplicate (20-25). Nitrogen-free extracts (NFE) were calculated as follows:

\section{$\mathrm{NFE}=\mathrm{DM}-(\mathrm{CP}+\mathrm{CA}+\mathrm{CF}+\mathrm{EE})$}

The amino acid content was determined using an amino acid analyzer type AAA-339 (Mikrotechna, Prague, Czech Republic) using ninhydrin for post-column derivatization. Before analysis, the samples were hydrolyzed with 6 $\mathrm{M} \mathrm{HCl}$ for $24 \mathrm{~h}$ at $110{ }^{\circ} \mathrm{C} \mathrm{(26).} \mathrm{The} \mathrm{phytate} \mathrm{content} \mathrm{was}$ analyzed according to AOAC method 986.11 (27). The protein biological value was determined by the following indices: the chemical score was calculated using Mitchell and Block's method (28), the essential amino acid index (EAAI) was calculated with Oser's method (29), the tryptophan concentration was not determined chemically and it was assumed to be $0.72 \mathrm{~g}$ per $100 \mathrm{~g}$ of protein in raw and fermented lupin seeds, and digestible protein was determined by the enzymatic method.

Metabolizable energy in diets for pigs was calculated according to the recommendations of German Society of Nutrition Physiology (30) using the same digestibility coefficients for lupin and lupin products.

Lupin alkaloids were extracted from flour by trichloroacetic acid and methylene chloride, and determined with gas chromatograph model GC-17A (Shimadzu Corp., Kyoto, Japan) with a capillary column (Phenomenex, Torrance, CA, USA). Raffinose family oligosaccharides were extracted and analyzed by high-resolution gas chromatography as described previously by Zalewski et al. (31). The $\mathrm{pH}$ was measured in $10 \%$ water extract by a $\mathrm{pH}$ meter inoLab $^{\circledR}$ (WTW, Weilheim, Germany). For organic acid determination, the extract was centrifuged at $10000 \times g$ for 8 min. All samples were filtered through a $0.20-\mathrm{mm}$ filter before HPLC analysis. The supernatant was analysed directly by the HPLC method using a UV detector (Waters Corp., Milford, MA, USA). Organic acids were separated on an Aminex HPX-87H column (Bio-Rad, Hercules, CA, USA) at $65^{\circ} \mathrm{C}$ using $5 \mathrm{mmol} / \mathrm{L}$ of $\mathrm{H}_{2} \mathrm{SO}_{4}$ as the eluent, at a flow rate of $0.5 \mathrm{~mL} / \mathrm{min}$.

\section{Statistical analyses}

One-way analysis of variance was performed. The significance of differences between control and experimental groups was calculated by Duncan`s global test, and an alpha level of $p<0.05$ was used to assess the significance among the mean values. The statistical analysis was performed using STATGRAPHICS, v. 5.0 (Statpoint Technologies, Inc., Warrenton, VA, USA). 


\section{Results}

All the products were characterized by a similar fresh and final dry matter content (Table 1). In comparison with raw lupin seeds, the content of crude ash and acid detergent fibre $(A D F)$ significantly increased $(p<0.05)$ in all fermented products, whereas the ether extract and nitrogen-free extract (NFE) contents significantly decreased $(p<0.05)$.
The metabolizable energy was similar in all the samples. A significant $(p<0.05)$ increase in the mass fractions of alanine in the protein of the products fermented with baker's yeast, Bayanus G-995 and Fermivin 7013, and lysine in products fermented with Fermivin 7013 and $S$. carlbergensis was found in comparison with unprocessed seeds (Table 2). The arginine level decreased significantly

Table 1. Composition of lupin seeds and fermented products expressed on dry matter basis

\begin{tabular}{|c|c|c|c|c|c|c|c|}
\hline \multirow{2}{*}{$w /(\mathrm{g} / \mathrm{kg})$} & \multirow{2}{*}{$\begin{array}{l}\text { Lupin } \\
\text { seeds }\end{array}$} & \multicolumn{4}{|c|}{ Fermented product } & \multirow{2}{*}{ SEM } & \multirow{2}{*}{ p-value } \\
\hline & & Baker's yeast & Bayanus G-995 & Fermivin 7013 & S. carlsbergensis & & \\
\hline Fresh dry matter & - & 203.1 & 203.7 & 210.6 & 199.6 & 2.1 & 0.350 \\
\hline Final dry matter & 957.1 & 940.4 & 956.4 & 963.5 & 956.4 & 3.7 & 0.359 \\
\hline Crude protein & 330.3 & 362.9 & 358.8 & 360.0 & 358.5 & 2.2 & 0.093 \\
\hline Digestible protein & $262.1^{b}$ & $304.8^{\mathrm{a}}$ & $290.8^{\mathrm{a}}$ & $300.5^{\mathrm{a}}$ & $296.1^{\mathrm{a}}$ & 0.2 & 0.012 \\
\hline Crude fibre & 174.1 & 184.1 & 189.0 & 177.7 & 185.4 & 1.6 & 0.103 \\
\hline Ether extract & $46.4^{\mathrm{a}}$ & $40.3^{b}$ & $40.1^{b}$ & $41.3^{\mathrm{b}}$ & $41.9^{\mathrm{b}}$ & 4.3 & 0.018 \\
\hline NFE & $367.6^{\mathrm{a}}$ & $309.5^{c}$ & $324.6^{\mathrm{bc}}$ & $339.9^{b}$ & $325.0^{\mathrm{bc}}$ & 3.2 & 0.009 \\
\hline $\mathrm{ADF}$ & $188.7^{\mathrm{c}}$ & $240.2^{\mathrm{ab}}$ & $243.7^{\mathrm{a}}$ & $229.7^{\mathrm{b}}$ & $226.9^{\mathrm{b}}$ & 2.2 & 0.049 \\
\hline $\mathrm{NDF}$ & 246.1 & 266.0 & 272.7 & 257.6 & 253.7 & 3.1 & 0.204 \\
\hline
\end{tabular}

Values in the same row with different letters in superscript differ significantly at $\mathrm{p}<0.05$

$\mathrm{SEM}=$ standard error of the mean, NFE=nitrogen-free extract, $\mathrm{ADF}=$ acid detergent fibre, NDF=neutral detergent fibre,

$\mathrm{ME}=$ metabolizable energy

Table 2. Amino acid content in proteins and biological values of raw lupin seeds and fermented products

\begin{tabular}{|c|c|c|c|c|c|c|c|}
\hline \multirow{2}{*}{$\frac{w \text { (amino acid) }}{\mathrm{g} / 100 \mathrm{~g}}$} & \multirow{2}{*}{$\begin{array}{l}\text { Lupin } \\
\text { seeds }\end{array}$} & \multicolumn{4}{|c|}{ Fermented product } & \multirow{2}{*}{ SEM } & \multirow{2}{*}{ p-value } \\
\hline & & Baker's yeast & Bayanus G-995 & Fermivin 7013 & S. carlsbergensis & & \\
\hline \multicolumn{8}{|l|}{ Essential } \\
\hline Arginine & $12.17^{\mathrm{a}}$ & $8.17^{\mathrm{b}}$ & $8.17^{\mathrm{b}}$ & $8.75^{\mathrm{b}}$ & $10.18^{\mathrm{ab}}$ & 0.26 & 0.050 \\
\hline Histidine & 3.75 & 3.02 & 3.70 & 2.98 & 2.38 & 0.17 & $>0.05$ \\
\hline Isoleucine & 3.54 & 3.86 & 3.83 & 3.81 & 3.78 & 0.03 & $>0.05$ \\
\hline Leucine & 5.90 & 6.51 & 6.39 & 6.48 & 6.33 & 0.04 & $>0.05$ \\
\hline Lysine & $5.26^{\mathrm{bc}}$ & $5.52^{\mathrm{ab}}$ & $5.14^{c}$ & $5.72^{\mathrm{a}}$ & $5.64^{\mathrm{a}}$ & 0.03 & 0.019 \\
\hline Methionine & 0.53 & 0.50 & 0.58 & 0.58 & 0.59 & 0.03 & $>0.05$ \\
\hline Phenylalanine & 3.48 & 3.87 & 4.40 & 3.75 & 3.78 & 0.15 & $>0.05$ \\
\hline Threonine & $3.27^{\mathrm{a}}$ & $3.32^{\mathrm{a}}$ & $3.31^{\mathrm{a}}$ & $3.10^{\mathrm{b}}$ & $3.21^{\mathrm{ab}}$ & 0.02 & 0.029 \\
\hline Valine & 3.57 & 3.78 & 3.83 & 3.77 & 3.74 & 0.03 & $>0.05$ \\
\hline Cystine & 1.38 & 1.70 & 1.46 & 1.38 & 1.36 & 0.05 & $>0.05$ \\
\hline \multicolumn{8}{|l|}{ Non-essential } \\
\hline Alanine & $3.03^{c}$ & $3.41^{\mathrm{ab}}$ & $3.36^{\mathrm{ab}}$ & $3.50^{\mathrm{a}}$ & $3.21^{\mathrm{bc}}$ & 0.03 & 0.032 \\
\hline Aspartic acid & 8.95 & 9.42 & 9.20 & 9.25 & 9.15 & 0.07 & $>0.05$ \\
\hline Glutamic acid & 22.74 & 22.19 & 22.47 & 22.62 & 21.85 & 0.07 & $>0.05$ \\
\hline Glycine & 3.98 & 4.25 & 4.16 & 4.20 & 4.05 & 0.03 & $>0.05$ \\
\hline Proline & 5.58 & 5.64 & 5.96 & 5.79 & 5.87 & 0.07 & $>0.05$ \\
\hline Serine & 4.39 & 4.34 & 4.44 & 4.19 & 4.24 & 0.02 & $>0.05$ \\
\hline Tyrosine & 3.47 & 5.46 & 4.50 & 5.12 & 5.60 & 0.20 & $>0.05$ \\
\hline Chemical score & 33 & 38 & 35 & 34 & 34 & 0.45 & 0.165 \\
\hline EAAI & $62^{\mathrm{b}}$ & $69^{\mathrm{a}}$ & $68^{\mathrm{a}}$ & $68^{\mathrm{a}}$ & $69^{a}$ & 0.40 & 0.007 \\
\hline TEAA & $42.85^{\mathrm{a}}$ & $40.25^{c}$ & $40.81^{\mathrm{bc}}$ & $40.32^{\mathrm{bc}}$ & $40.99^{b}$ & 0.26 & 0.001 \\
\hline
\end{tabular}

Values in the same row with different letters in superscript differ significantly at $\mathrm{p}<0.05$

$\mathrm{SEM}=$ standard error of the mean, EAAI=essential amino acid index, TEAA=total essential amino acids (100 $\mathrm{g}$ per $\mathrm{g}$ of protein) 
$(\mathrm{p}<0.05)$ in the products fermented with baker's yeast, Bayanus G-995 and Fermivin 7013 and threonine in those with Fermivin 7013. Chemical score increased $(p>0.05)$ from 33 in raw lupin seeds to 34 in the products obtained with Fermivin 7013 and S. carlbergensis, to 35 in those with Bayanus G-995 and 38 with baker's yeast, whereas essential amino acid index $($ EEAI) increased $(p<0.05)$ from 62 in lupin seeds to 68 in those fermented with Bayanus G-995 and Fermivin 7013 or to 69 in those with baker's yeast and $S$. carlsbergensis. In each case, methionine and cystine were the limiting amino acids. The total essential amino acid (TEAA) index was lower $(p<0.05)$ in all the fermented products than in raw seeds. No significant effect of yeast fermentation $(p>0.05)$ on the total alkaloid mass fraction and structure was found (Table 3). The mass fraction of phytate was significantly lower in the products fermented with Fermivin 7013 and S. carlbergensis than in raw seeds. During fermentation, the reduction of total raffinose family oligosaccharides $(\mathrm{p}<0.05)$ was found in all the samples. The $\mathrm{pH}$ of the starting material was about 5.5. In fermented products, the $\mathrm{pH}$ decreased (Table 4) and ranged from 5.1 to 4.3 . The $\mathrm{pH}$ of the seeds fermented with Bayanus G-995 was significantly lower than in other preparations. The mass fraction of lactic acid (in $\mathrm{g} / \mathrm{kg}$ ) ranged from 13.45 to 35.05 , of butyric acid from 0 to 0.70 , of propionic acid from 14.05 to 18.35 and of acetic acid from 4.70 to 5.21 . The mass fraction of lactic acid in the seeds fermented with baker's yeast was significantly lower $(\mathrm{p}<0.05)$ and acetic acid in the seeds fermented with $S$. carlsbergensis was significantly higher $(p<0.05)$ than in other preparations. The mass fraction of propionic acid in seeds fermented with $S$. carlsbergensis and Fermivin 7013 was significantly higher $(\mathrm{p}<0.05)$ than in those with Bayanus G995 and baker's yeast.

\section{Discussion}

Fermentation conditions for optimum biomass increase in the first $24 \mathrm{~h}$ were described in other studies $(16,32,33)$. The dry matter loss did not exceed $10 \%$. All yeast strains used in the experiment showed the tendency (at $p=0.09$ ) to increase the content of digestible proteins in dry matter (on average by $10 \%$ ), which was correlated with a decrease in NFE content, used probably as a carbon source by the yeast. A similar increase in the protein content was observed in the study by Nguyen et al. (34) during fermentation of pea seeds and wheat grains using Saccharomyces boulardii. The increase in protein content was associated with biomass production $(8,31)$, which was confirmed by higher protein digestibility $(\mathrm{p}=0.01)$. Yeast uses available sources of nitrogen as free amino acids, dipeptides or proteins for growth (35). In the fermented products a negligible increase in the mass fractions of some essential amino acids was observed, which contributed to the improve-

Table 3. The mass fractions of total alkaloids, total oligosaccharides and phytate, and alkaloid and oligosaccharide compositions in lupin seeds and fermented products

\begin{tabular}{|c|c|c|c|c|c|c|c|}
\hline \multirow{2}{*}{ Compound } & \multirow{2}{*}{$\begin{array}{l}\text { Lupin } \\
\text { seeds }\end{array}$} & \multicolumn{4}{|c|}{ Fermented product } & \multirow{2}{*}{ SEM } & \multirow{2}{*}{ p-value } \\
\hline & & Baker's yeast & Bayanus G-995 & Fermivin 7013 & S. carlsbergensis & & \\
\hline$\overline{w \text { (total alkaloids) } /(\mathrm{g} / \mathrm{kg})}$ & 0.24 & 0.23 & 0.19 & 0.22 & 0.24 & 0.01 & $>0.05$ \\
\hline$w$ (angustifoline in TA) $/ \%$ & 11.35 & 11.77 & 9.31 & 10.69 & 10.98 & 0.29 & $>0.05$ \\
\hline$w($ isolupanine in TA) $/ \%$ & 4.07 & 3.99 & 4.23 & 3.98 & 3.94 & 0.03 & $>0.05$ \\
\hline$w($ lupanine in TA) $/ \%$ & 61.34 & 62.19 & 63.34 & 62.71 & 62.01 & 0.35 & $>0.05$ \\
\hline$w(13-\mathrm{OH}-$ lupanine in TA)/\% & 23.24 & 22.06 & 23.13 & 22.62 & 23.08 & 0.28 & $>0.05$ \\
\hline$w($ phytate $) /(\mathrm{mg} / \mathrm{kg})$ & $1.90^{\mathrm{a}}$ & $1.05^{\mathrm{ab}}$ & $0.96^{\mathrm{ab}}$ & $0.71^{\mathrm{b}}$ & $0.39^{\mathrm{b}}$ & 0.12 & 0.008 \\
\hline$w($ total oligosaccharides $) /(\mathrm{g} / \mathrm{kg})$ & $73.6^{\mathrm{a}}$ & $0.00^{\mathrm{b}}$ & $0.00^{\mathrm{b}}$ & $0.00^{\mathrm{b}}$ & $0.00^{\mathrm{b}}$ & 32.2 & 0.010 \\
\hline$w($ raffinose in $\mathrm{TO}) / \%$ & $12.2^{\mathrm{a}}$ & $0.00^{\mathrm{b}}$ & $0.00^{\mathrm{b}}$ & $0.00^{\mathrm{b}}$ & $0.00^{\mathrm{b}}$ & 0.00 & 0.010 \\
\hline$w($ stachyose in $\mathrm{TO}) / \%$ & $41.5^{\mathrm{a}}$ & $0.00^{\mathrm{b}}$ & $0.00^{\mathrm{b}}$ & $0.00^{\mathrm{b}}$ & $0.00^{\mathrm{b}}$ & 0.00 & 0.010 \\
\hline$w($ verbascose in $\mathrm{TO}) / \%$ & $19.9^{\mathrm{a}}$ & $0.00^{\mathrm{b}}$ & $0.00^{\mathrm{b}}$ & $0.00^{\mathrm{b}}$ & $0.0^{\mathrm{b}}$ & 0.00 & 0.010 \\
\hline
\end{tabular}

Values in the same row with different letters in superscript differ significantly at $p<0.05$

$\mathrm{SEM}=$ standard error of the mean, $\mathrm{TA}=$ total alkaloids, $\mathrm{TO}=$ total oligosaccharides

Table 4. The $\mathrm{pH}$ value and organic acid concentration on dry matter basis in fermented products

\begin{tabular}{|c|c|c|c|c|c|c|}
\hline \multirow{2}{*}{$w($ organic acid $) /(\mathrm{g} / \mathrm{kg})$} & \multicolumn{4}{|c|}{ Fermented products } & \multirow{2}{*}{ SEM } & \multirow{2}{*}{$\mathrm{p}$-value } \\
\hline & Baker's yeast & Bayanus G-995 & Fermivin 7013 & S. carlsbergensis & & \\
\hline Lactic & $13.45^{\mathrm{b}}$ & $30.90^{\mathrm{a}}$ & $35.05^{\mathrm{a}}$ & $27.00^{\mathrm{a}}$ & 1.39 & 0.018 \\
\hline Acetic & $5.21^{\mathrm{b}}$ & $5.06^{\mathrm{b}}$ & $4.70^{\mathrm{b}}$ & $6.00^{\mathrm{a}}$ & 0.08 & 0.009 \\
\hline Propionic & $14.05^{\mathrm{b}}$ & $13.55^{\mathrm{b}}$ & $18.35^{\mathrm{a}}$ & $17.50^{\mathrm{a}}$ & 0.35 & 0.022 \\
\hline Butyric & 0.05 & 0.00 & 0.70 & 0.05 & 0.18 & $>0.05$ \\
\hline$\overline{\mathrm{pH}}$ & $5.1^{\mathrm{a}}$ & $4.3^{\mathrm{c}}$ & $4.7^{\mathrm{b}}$ & $4.7^{\mathrm{b}}$ & 0.03 & 0.012 \\
\hline
\end{tabular}

Values in the same row with different letters in superscript differ significantly at $\mathrm{p}<0.05$

$\mathrm{SEM}=$ standard error of the mean 
ment of seed protein indices: chemical score (up 1 to 5 units) and EAAI (up 6 to 7 units), as was also confirmed by Trojanowska et al. (11), Khattab et al. (14) and Yabaya et al. (16). Only the arginine content decreased significantly $(p<0.05)$ in the seeds fermented with baker's yeast, Bayanus G-995 and Fermivin 7013, which had a negative impact on the TEAA index. Arginine is used by yeast as a precursor of other amino acids, and this phenomenon was also observed by Yabaya et al. (16). The most preferred indices of the protein were found in the product fermented by baker's yeast, which also contained more cystine $(\mathrm{p}>0.05)$ than the other products.

Lupin seeds are a difficult material for fermentation by yeast because of the lack of easily accessible starch (10). The carbohydrates found in lupin seeds consist mainly of simple sugars (about $30 \mathrm{~g} / \mathrm{kg}$ ), and raffinose family sugars (about $76 \mathrm{~g} / \mathrm{kg}$ ) (9). Carbohydrates of the raffinose family have been used completely by the yeast during 24 $\mathrm{h}$ of fermentation (36). On the other hand, the total use of available sugars (NFE) was relatively low and did not exceed $17 \%$, which could be partly a result of short fermentation time. Structural sugars proved to be resistant to indirect digestion by the used yeast, which is confirmed by high levels of carbohydrate complexes (as crude fibre, ADF and NDF) in the fermented seeds (37). Moreover, the increase in the NDF content in some technological treatments is usually accompanied by an increase in NDF-bound protein and reduced availability (38). It can be assumed that the increase in the ADF and NDF fractions in fermented products can indicate a higher degree of protein binding by the fibre.

Yeasts are also a rich source of minerals and, depending on the species and strain, may introduce into the fermented mass from 4 up to $10 \%$ of ash (10), which was confirmed by our research. The level of fat in the fermented products was lower than in raw seeds, which was also found by Yabaya et al. (16), Mbata et al. (32) and Hassan et al. (37). The yeast used fat as an energy source to produce cell biomass.

Generally, fermentation caused a decrease in the fat and carbohydrate content in the seeds, which can lead to changes in the metabolic energy value. However, metabolizable energy, calculated on the basis of the chemical composition, indicates that fermentation did not reduce it. It should be noted that digestibility coefficients of nutrients in lupin seeds were taken into account in the metabolizable energy calculation, while fermentation may really affect the digestibility of protein (e.g. in vitro digestibility of protein was improved by about $13 \%$ ) or carbohydrates. These results should therefore be treated as rough approximation.

No significant effect of yeast fermentation $(\mathrm{p}>0.05)$ on total alkaloid mass fraction and structure was found. Trojanowska et al. (11) observed that the development of different yeast strains on lupin extract can lead to a reduction in the alkaloid content by up to $20 \%$ (as was confirmed in the case of seeds fermented with Bayanus G-995). It should be noted, however, that the lupin extract contained mainly alkaloidal nitrogen (about $10 \%$ dry matter), free amino acids or peptides (about $7 \%$ dry matter), and only small amounts of protein. Due to the unavaila- bility of a more absorbable form of nitrogen, the yeast may use the nitrogen bound in the form of alkaloids. In contrast, the lupin seeds contain significant amounts of protein, but low mass fractions of alkaloids $(2.4 \mathrm{mg} / \mathrm{kg}$ in raw seeds), which promotes nitrogen utilization for biomass production.

In all the fermented products, the phytate mass fraction was reduced, which was confirmed by other studies $(15,37,39)$. The Saccharomyces carlsbergensis and Saccharomyces cerevisiae strain 7013 proved to be the most effective as they reduced the phytate content by approx. 80 and 63 $\%$, respectively $(\mathrm{p}<0.05)$. The observed changes confirm the opinion that fermentation increases the activity of native phytase, which can disintegrate insoluble organic complexes with minerals $(13,40)$.

Raffinose family oligosaccharides are considered to be antinutritional factors responsible for excessive formation of gases and diarrhoea after feeding animals with raw legume seeds. These carbohydrates were used during fermentation by yeast due to their availability resulting from the enzymatic activity of microorganisms. Yeast produces different types of glycosyl hydrolases, such as $\alpha$-D-galactosidase, which degrade the oligosaccharides into simple sugars (36). Trojanowska et al. (11) found that different yeast strains are able to degrade up to $70 \%$ of oligosaccharides, with approx. $50 \%$ of their participation in the lupin extract.

During fermentation, yeast also produces organic acids, as a result of sugar and glycerol degradation, which reduces the $\mathrm{pH}(19,33)$. Yabaya et al. $(16)$ observed a similar reduction in the initial $\mathrm{pH}$ from 5.6 to 5.1 , and a significant increase in the yeast count during the fermentation of soya cake by Saccharomyces cerevisiae for $24 \mathrm{~h}$. Mbata et al. (32) found a decrease in the $\mathrm{pH}$ from 6.5 to 4.5 during fermentation of bambara groundnut. The composition of organic acids was not given by the authors cited above. In the present study mass fractions of lactic, acetic, propionic and butyric acids in the final products were investigated. The short-chain fatty acids, such as acetic, propionic and butyric, are by-products of fermentation, although the presence of propionic and butyric acids may also be associated with the activity of bacteria (41). Sripriya et al. (35) observed that lactic acid appeared in a significant amount from the 6th $\mathrm{h}$ of fermentation and steadily increased up to $37 \mathrm{~g} / \mathrm{kg}$ in $48 \mathrm{~h}$, while in this study, the lactic acid mass fraction ranged from 13 to $35 \mathrm{~g} / \mathrm{kg}$. The lactic acid mass fraction was the highest in the seeds fermented with Fermivin 7013, in which the highest mass fraction of butyric acid was also found. Acetic acid formation by Saccharomyces cerevisiae strains is affected by sugar concentration, $\mathrm{pH}$ and nitrogen (41). Van Winsen et al. (42) pointed out that low $\mathrm{pH}$ level and especially the high lactic acid concentration are the main factors responsible for the antimicrobial effect of fermented feed and can have a beneficial effect on feed intake, daily gain and feed/gain ratio $(42,43)$.

Generally, for better fermentation effects, the time of the process should be extended and the initial hydrolysis of the material should be applied. Moreover, in our opinion, yeast strains that degrade structural carbohydrates should be used. For this reason, the study should be continued. 


\section{Conclusions}

Yeast fermentation of lupin seeds allows formation of valuable feed or food products. The benefit of the process is primarily a reduction of some antinutritional factors, as well as lowering the $\mathrm{pH}$, and favouring the formation of probiotic lactic acid bacteria in the products. Fermentation of lupin seeds increased their nutritional value, especially by increasing the protein content and improving the amino acid profile. The Saccharomyces cerevisiae baker's yeast and Fermivin 7013 strain proved to be the most effective for direct fermentation of blue lupin seeds.

\section{Acknowledgements}

The study was supported by the National Research Centre grant No. 2011/01/B/NZ9/00232.

\section{References}

1. Jezierny D, Mosenthin R, Bauer E. The use of grain legumes as a protein source in pig nutrition: a review. Anim Feed Sci Technol. 2010;157:111-28.

http://dx.doi.org/10.1016/j.anifeedsci.2010.03.001

2. Kaczmarek SA, Kasprowicz-Potocka M, Hejdysz M, Mikuła $\mathrm{R}$, Rutkowski A. The nutritional value of narrow-leafed lupin (Lupinus angustifolius) for broilers. J Anim Feed Sci. 2014;23:160-6.

3. Gulewicz P, Martinez-Villaluenga C, Kasprowicz-Potocka M, Frias J. Non-nutritive compounds in Fabaceae family seeds and the improvement of their nutritional quality by traditional processing - a review. Pol J Food Nutr Sci. 2014;64:7589.

http://dx.doi.org/10.2478/v10222-012-0098-9

4. Ciesiołka D, Gulewicz P, Matrinez-Villaluenga C, Pilarski R, Bednarczyk M, Gulewicz K. Products and biopreparations from alkaloid-rich lupin in animal nutrition and ecological agriculture. Folia Biol (Krakow). 2005;53:59-66. http://dx.doi.org/10.3409/173491605775789443

5. Kasprowicz-Potocka M, Chilomer K, Zaworska A, Nowak W, Frankiewicz A. The effect of feeding raw and germinated Lupinus luteus and Lupinus angustifolius seeds on the growth performance of young pigs. J Anim Feed Sci. 2013;22: 116-21.

6. Chilomer K, Kasprowicz-Potocka M, Gulewicz P, Frankiewicz A. The influence of lupin seed germination on the chemical composition and standardized ileal digestibility of protein and amino acids in pigs. J Anim Physiol An N. 2013; 97:639-46.

http://dx.doi.org/10.1111/j.1439-0396.2012.01304.x

7. Martínez-Villaluenga C, Frías J, Gulewicz P, Gulewicz K, Vidal-Valverde C. Food safety evaluation of broccoli and radish sprouts. Food Chem Toxicol. 2008;46:1635-44. http://dx.doi.org/10.1016/j.fct.2008.01.004

8. Bekatorou A, Psarianos C, Koutinas AA. Production of food grade yeasts. Food Technol Biotechnol. 2006;44:407-15.

9. Yoon SH, Mukerjea R, Robyt JF. Specificity of yeast (Saccharomyces cerevisiae) in removing carbohydrates by fermentation. Carbohydr Res. 2003;338:1127-32. http://dx.doi.org/10.1016/S0008-6215(03)00097-1

10. Dobrzański Z, Dolińska B, Chojnacka K, Opaliński S, Ryszka F. Using of yeast in animal nutrition. Acta Sci Pol Med Vet. 2006;5:49-66 (in Polish).

11. Trojanowska K, Markiewicz M, Czaczyk K, Mueller A, Gulewicz K. Lupine extract as a source in feed protein biosynthesis on microbial way. Biotechnologia. 1991;3-4:131-6 (in Polish).
12. Khetarpaul N, Chauhan BM. Biological utilisation of pearl millet flour fermented with yeasts and lactobacilli. Plant Foods Hum Nutr. 1991;41:309-19.

http://dx.doi.org/10.1007/BF02310625

13. Shindu SC, Khetarpaul N. Fermentation with one step single and sequential cultures of yeast and lactobacilli: effect on antinutrients and digestibilities (in vitro) of starch and protein in an indigenously developed food mixture. Plant Foods Hum Nutr. 2003;58:1-10.

http://dx.doi.org/10.1023/B:QUAL.0000040326.72490.83

14. Khattab RY, Arntfield SD, Nyachoti CM. Nutritional quality of legume seeds as affected by some physical treatments, part 1: protein quality evaluation. LWT - Food Sci Technol. 2009;42:1107-12.

http://dx.doi.org/10.1016/j.lwt.2009.02.008

15. Khattab RY, Arntfield SD. Nutritional quality of legume seeds as affected by some physical treatments 2 . antinutritional factors. LWT - Food Sci Technol. 2009;42:1113-8. http://dx.doi.org/10.1016/j.lwt.2009.02.004

16. Yabaya A, Akinyanju JA, Jatau ED. Yeast enrichment of soybean cake. World J Dairy Food Sci. 2009;4:141-4.

17. Ogunremi OR, Sanni AI, Agrawal R. Probiotic potentials of yeasts isolated from some cereal-based Nigerian traditional fermented food products. J Appl Microbiol. 2015;119:797-808. http://dx.doi.org/10.1111/jam.12875

18. Fowler J, Kakani R, Haq A, Byrd JA, Bailey CA. Growth promoting effects of prebiotic yeast cell wall products in starter broilers under an immune stress and Clostridium perfringens challenge. J Appl Poult Res. 2015;24:66-72. http://dx.doi.org/10.3382/japr/pfv010

19. Ferreira IMPLVO, Pinho O, Vieira E, Tavarela JG. Brewer's Saccharomyces yeast biomass: characteristics and potential applications. Trends Food Sci Technol. 2010;21:77-84. http://dx.doi.org/10.1016/j.tifs.2009.10.008

20. AOAC Official Method 934.01. Moisture in animal feed. Agricultural chemicals. Gaithersburg, MD, USA: AOAC International; 2007.

21. AOAC Official Method 976.05. Protein (crude) in animal feed, forage (plant tissue), grain, and oilseeds. Agricultural chemicals. Gaithersburg, MD, USA: AOAC International; 2007.

22. AOAC Official Method 920.39. Fat (crude) or ether extract in animal feed. Agricultural chemicals. Gaithersburg, MD, USA: AOAC International; 2007.

23. AOAC Official Method 978.10. Fiber (crude) in animal feed and pet food. Agricultural chemicals. Gaithersburg, MD, USA: AOAC International; 2007.

24. AOAC Official Method 942.05. Determination of ash in animal feed. Agricultural chemicals. Gaithersburg, MD, USA: AOAC International; 2007.

25. AOAC Official Method 973.18. Acid detergent fiber. Agricultural chemicals. Gaithersburg, MD, USA: AOAC International; 2007.

26. AOAC Official Method 994.12. Amino acids in feeds. Agricultural chemicals. Gaithersburg, MD, USA: AOAC International; 2007.

27. AOAC Official Method 986.11, Phytate in foods. Agricultural chemicals. Gaithersburg, MD, USA: AOAC International; 2007.

28. Mitchell HH, Block RJ. Some relationships between the amino acid contents of proteins and their nutritive values for the rat. J Biol Chem. 1946;163:559-620.

29. Oser BL. An integrated essential amino acid index for predicting the biological value of proteins. In: Albanese AA, editor. Protein and amino acid nutrition. New York, NY, USA: Academic Press; 1959. pp. 281-95. 
30. Committee for Requirement Standards of the German Society of Nutrition Physiology, vol. 10. Frankfurt, Germany: DLG-Verlag GmbH; 2006 (in German).

31. Zalewski K, Lahuta LB, Horbowicz M. The effect of soil drought on the composition of carbohydrates in yellow lupin seeds and triticale kernels. Acta Physiol Plant. 2001; 23:73-8. http://dx.doi.org/10.1007/s11738-001-0025-x

32. Mbata TI, Ikenebomeh MJ, Alaneme JC. Studies on the microbiological, nutrient composition and antinutritional contents of fermented maize flour fortified with bambara groundnut (Vigna subterranean L.). Afr J Food Sci. 2009;3: 165-71.

33. Kasprowicz-Potocka M, Borowczyk P, Gulewicz P, Zaworska A, Frankiewicz A. Optimization of the fermentation conditions for blue lupin seeds sing the yeast Saccharomyces cerevisiae towards maximizing the production of protein. Fragm Agronom. 2012;29:78-86 (in Polish).

34. Nguyen TH, Herve M. Food ingredients obtained by fermentation with S. boulardii and foods containing them. US patent 5639496. 1997.

35. Sripriya G, Usha A, Chandra TS. Changes in carbohydrate, free amino acids, organic acids, phytate and $\mathrm{HCl}$ extractability of minerals during germination and fermentation of finger millet (Eleusine coracana). Food Chem. 1997;58:345-50. http://dx.doi.org/10.1016/S0308-8146(96)00206-3

36. Egounlety M, Aworth OC. Effect of soaking, dehulling, cooking and fermentation with Rhizopus oligosporus on the oligosaccharides, trypsin inhibitor, phytic acid and tannins of soybean (Glycine max Merr.), cowpea (Vigna unguiculata L. Walp) and groundbean (Macrotyloma geocarpa Harms). J Food Eng. 2003;56:249-54. http://dx.doi.org/10.1016/S0260-8774(02)00262-5
37. Hassan EG, Awad Alkareem AM, Mustafa AMI. Effect of fermentation and particle size of wheat bran on the antinutritional factors and bread quality. Pak J Nutr. 2008;7:521-6. http://dx.doi.org/10.3923/pjn.2008.521.526

38. Pastuszewska B, Dakowski P, Jabłecki G, Buraczewska L, Ochtabińska A, Święch E, et al. Effects of toasting rapeseed meal and heating defatted rapeseed cake on their protein value determined in vitro and in vivo. Oilseed Crops. 2001; 22:241-6 (in Poilsh).

39. Servi S, Özkaya H, Colakoglu AS. Dephytinization of wheat bran by fermentation with bakers' yeast, incubation with barley malt flour and autoclaving at different $\mathrm{pH}$ levels. J Cereal Sci. 2008;48:471-6. http://dx.doi.org/10.1016/j.jcs.2007.10.011

40. Chu GM, Ohmori H, Kawashima T, Funaba M, Matsui T. Brewer's yeast efficiently degrades phytate phosphorus in a corn-soybean meal diet during soaking treatment. Anim Sci J. 2009;80:433-7. http://dx.doi.org/10.1111/j.1740-0929.2009.00651.x

41. Lambrechts MG, Pretorius IS. Yeast and its importance to wine aroma - a review. S Afr J Enol Vitic. 2000;21:97-129.

42. van Winsen RL, Urlings BAP, Lipman LJA, Snijders JMA, Keuzenkamp D, Verheijd en JHM, van Knapen F. Effect of fermented feed on the microbial population of the gastrointestinal tracts of pigs. Appl Environ Microbiol. 2001;67:30716. http://dx.doi.org/10.1128/AEM.67.7.3071-3076.2001

43. Missotten JAM, Michiels J, Ovyn A, De Smet S, Dierick NA. Fermented liquid feed for pigs: a review. Archiv Anim Nutr. 2010;64:437-66. http://dx.doi.org/10.1080/1745039X.2010.512725 